\title{
Embodying Sound \\ A work-in-progress on technologically expanded performance
}

\author{
Bruno Pedro \\ Laboratório de Biomecânica e \\ Morfologia Funcional \\ FMH/ Universidade de Lisboa \\ Lisboa, Portugal \\ bmpedro@fmh.ulisboa.pt
}

\author{
Cecília De Lima \\ INET-md: Projeto TEPe - FCT ref ${ }^{a}$ \\ PTDC/ART - PER/31263/2017 \\ FMH/ Universidade de Lisboa \\ Lisboa, Portugal \\ ceciliadelima@gmail.com \\ João Marques Carrilho \\ CESEM - Centro de Estudos em \\ Sociologia e Estética Musical \\ Lisboa, Portugal \\ jonasruna@gmail.com
}

\author{
Daniel Tércio \\ INET-md: Projeto TEPe - FCT ref \\ PTDC/ART - PER/31263/2017 \\ FMH/ Universidade de Lisboa \\ Lisboa, Portugal \\ danieltercio@gmail.com \\ André Viana \\ Faculdade de Motricidade \\ Humana, Universidade de Lisboa \\ Lisboa, Portugal \\ andreviana@fmh.ulisboa.pt
}

\begin{abstract}
Embodying Sound is a performing art project that integrates dance, music and digital technology, it explores a real-time sonification of human motion, captured by inertial sensors, using the XSens system. First and foremost, it is not a demonstration of technical virtuosity, but an attempt to put technology at the service of imagination and creativity. In a world dominated by computation - tending to a dystopic future of "artificial intelligences" [1], we tend to forget that present-day machines cannot really think or feel; Computers do not have purposes, do not love or understand reality the way a living organism does [2]. In this presentation, we explore how technology can act as a mediator between dance and music. The quest of this performative process is to investigate the sound signature of the body. Here we discuss how such phenomenological experience might challenge self-consciousness and the perception of identity. Furthermore, within a more general approach, we question how does this artistic and technological interaction stimulate the expansion of artistic expression, which might result in new aesthetics.
\end{abstract}

\section{CCS CONCEPTS}

Applied computing - Arts and humanities - Performing Arts.

Permission to make digital or hard copies of part or all of this work for personal or classroom use is granted without fee provided that copies are not made or distributed for profit or commercial advantage and that copies bear this notice and the full citation on the first page. Copyrights for third-party components of this work must be honored. For all other uses, contact the Owner/Author. ARTECH 2019, October 23-25, 2019, Braga, Portugal

(C) 2019 Copyright is held by the owner/author(s).

ACM ISBN 978-1-4503-7250-3/19/10.

https://doi.org/10.1145/3359852.3359971

\section{KEYWORDS}

Digital technology, Embodiment, Human motion, Performance, Sound signature, Dance, Motion track, Sound.

\section{ACM Reference format:}

B. Pedro, C. Lima, D. Tércio and J. Carrilho. 2019. Embodying Sound: A work-in-progress on technologically expanded performance. In Proceedings of ARTECH 2019, $9^{\text {th }}$ International Conference on Digital and Interactive Arts. (ARTECH 2019). October 23-25, 2019, Braga, Portugal. ACM, New York, NY, USA, 4 pages.

https://doi.org/10.1145/3359852.3359971

\section{Introduction}

Embodying Sound is artistic-technological project comprised within a larger research project called TEPe - Technologically Expanded Performance. This is an exploratory project crossing different fields and convening theoretical contributions from several approaches, where location is imagined as an itinerary instead of a fixed point. As Dwight Conquergood [3], we consider that performance studies struggle to open the space between analysis and action, and to pull the pin on binary opposition between theory and practice. TEPe forges interdisciplinarity in a terrain shared by performance studies, sound studies and urban studies. Interdisciplinarity, as we conceive it, is radical on the extent that it is challenging the edges between art and techno-science.

Embodying Sound started with a sensitive process: from the body as sound producer to the sound of the moving body. The target was a quest for the sound signature of the body. Somehow, we followed an approach similar for instance to that one that Yolande Harris [4], highlighting the contrasts between a bodily experience of a physical environment and technologies of invisibility and intangibility. Actually, we overlap the concept of 
soundscape with that one of bodyscape - both are embedded by Embodiment (a keyword in the interdisciplinary research on performing arts).

\section{Instrumentation methods}

Full body kinematics were recorded at $240 \mathrm{~Hz}$ with an inertial measurement units (IMUs) system (Xsens MVN, Xsens technologies, Enschede, Netherlands) synchronized with a video camera recording at $60 \mathrm{~Hz}$. The Xsens system consists in 17 IMU's placed over the feet, shanks, thighs, pelvis, sternum, head, scapula, upper arms, forearms and hands (Fig. 1) inside of a lycra suit. The placement of the sensors followed the manufactory recommendations [5] placing the IMU's over the over the bones whenever possible reducing soft tissue artefact (STA) [6]. The motion trackers were connected to a Body Pack that collected and transmit data the personal computer (PC).

Body dimensions as body height, shoe length, arm span, ankle height, hip height, hip width, knee height, shoulder width, shoulder height and shoe sole height were acquired for the participant. These measures inserted in Xsens MVN model adjusted body scaling and combined with others calibrations procedures (n-pose, walk and t-pose) provided the sensor to segment alignment [7]. A static and a dynamic calibration were performed for model reconstruction and to align the sensors with segment orientation. First the participants standing in npose, second they walked a few meters forward and return to initial position and, finally they standing again in n-pose, which consisted in standing in straight position with the palm of hands facing medially. Based on such settings data from the IMU's were integrated.

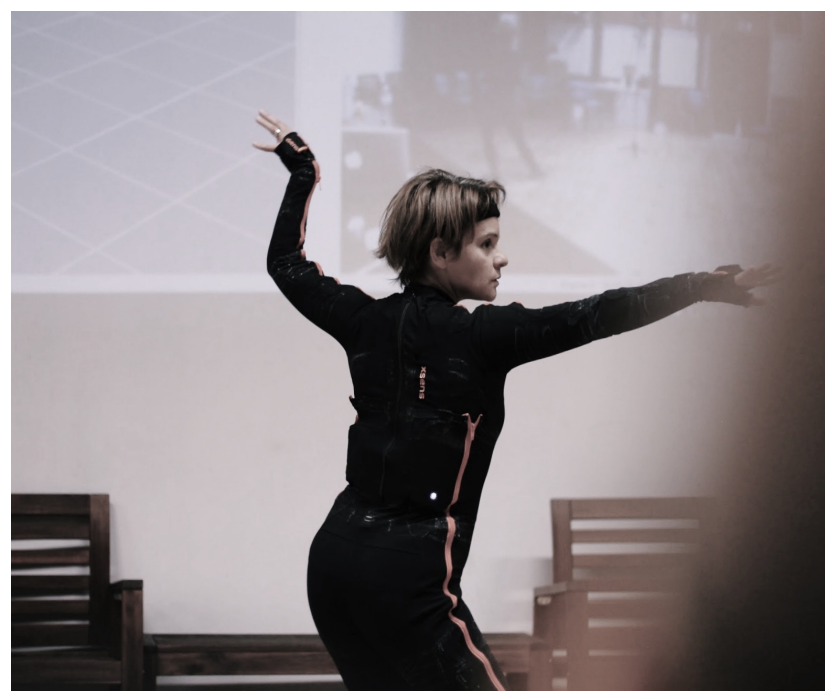

Figure 1: Performance Embodying Sound, June 2019 ๑ Ana Luísa Valdeira

\subsection{A general vision into the computing program - data processing}

The XSens produces large amounts of data, coming from its 33 sensors, each in three dimensions (using the Euler angles). This data, in 69 variables, is then sent to another computer, using the ethernet protocol, where it is received and processed in the Supercollider language. We developed four types of algorithms, to allow for greater flexibility in the dancer/musician interaction: 1) the accelerations are converted into triggers for previously recorded sounds; 2) the Euler angles are converted directly into parameters which manipulate the timbre and spatialization of pre-recorded sounds; 3) The Euler angles control different parameters of sound synthesis processes (in real-time), an approach which does not require any "sound library"; 4) the data is used as sound transformations (ring-modulation, convolution, etc.) on microphone inputs. The sonification of human motion, captured by inertial sensors, has been previously investigated by Hans-Peter Brückner, Christopher Bartels, and Holger Blume [8].

\section{The performative experience of generating sound with the body}

The sensors are placed in the body and to each sensor (and its three dimensions) there is the potential of associating one specific sound or different sorts of sound modulations. The basic sound is pre-recorded, but its rhythms, sequencing and different sorts of modulations (as for example: ring modulation, filtering, convolution, spatialization or pitch shifting) are now played by the body movement. With these settings, several varieties of exercises can be practiced.

Embodying Sound is a practice base source for broad research subjects like: how do the most recent technologies interfere with the body experience? Do digital technologies raise new tools for improvisation in performance? Nonetheless, our main quest with this project is to explore: how can the embodiment of sound and movement generate a sound signature of the body? If sound is simultaneously produced by movement, what happens between movement and sound signature?

Dancers and choreographers, similarly to artists from other disciplines, are often recognized by their characteristic artistic signature - a movement signature. This characteristic way of moving can be perceived not only on the body's features, but also on numerous other factors like: the manner of playing with body-weight, spatial and rhythmical relations, modes of effort and intension, body's muscular tone, etc. Such movement recognition is referred by Stern [9] as "Dynamic Forms of Vitality" - a basic living manifestation, displayed by our constant bodily movement. Stern sustains that the experience of vitality is something inherent to the animated living mode and it is so obvious and so incorporated within our perception that remains hidden in plain view. "We naturally experience people in terms of their vitality" (p.3), each person has a very characteristic way of expressing vitality, recognized in an intuitive manner, to which the author calls "dynamic movement signature". 
"Working for many years as a dancer, I recognize that my movement signature is not merely associated to one sort of movement quality, but it spans throughout numerous qualities. What I recognize as movement signature is correlated with an intrinsic mode of desire to incorporate diverse atmospheres or inputs through the creation of movement." 1

Hence, a movement signature is dynamic, not just by considering the nature of movement as intrinsically dynamic, but especially because the production of such movement derives from an animated desire, existing as a state of affection (after Deleuze and Guattari) [10]. Therefore, the primal desire for creating movement suffers affection by itself, in the sense that it is affected by and affects its own movement creation.

"In a first phase of this exploration, I play with the body's need for re-recognizing itself through his new output nature: I carefully attend to the production of sound, paying attention to how sound comes out of movement. The fresh reality of sound unfolding from movement invades my perception. The movement desire and the body motivation start to transform. Now, the motive is not only to play with movement sensations and relations, but another layer adds up: I start playing with sound-movement affairs. Proprioception gains a new voice and a strong sense of synesthetic reality starts to emerge. It is a synesthetic reality where new links appear, consciousness becomes more intense, but its defining borders become blur; it is as if the body gains new volumes and other modes of projection into the world. At the same time, I feel the weight of a greater sense of responsibility...” 2

Although our dynamic vitality is associated to a movement signature, and therefore to proprioception, here we search one other plane of vitality by looking into how movement signature can be transferred into sound signature. However, this transference exercise is not linear, it is not a merely transposition into other sensory output. In Embodying Sound, what moves the performer is, in itself, a generative relation where movement generates sound and sound motivates movement, hence, the movement signature is transformed. To borrow Merleau-Ponty [11] view, in which the artist transubstantiates into his artist media, in this case, the dancer doesn't transubstantiate merely into movement, but into a sound-movement relation. His intrinsic animate desire is not only about becoming movement but is about becoming movement-sound. Consequently, there is not a movement signature transferred into a sound signature but there is a movement-sound signature.

What can be the added value of this transformation on such form of vitality or dynamic movement signature?

In Embodying sound, we are expanding proprioception by incorporating sound to movement, and, as we have seen, the

\footnotetext{
${ }^{1}$ Excerpt of the project' report from Cecília de Lima (researcher and performer) ${ }^{2}$ Ibidem.
}

dynamic movement signature becomes transformed at its core. Following Damásio's theory of self-consciousness [12] 3, which demonstrates that exteroception and proprioception are core sensory modes of perception in the development of selfconsciousness, we can assume that such expanded perception of movement might also generate a change in the perception of relation of the organism to the environment, which is associated to a core modification of self-consciousness. In a subtle but basic mode, this performative exercise has the potential to question and transform the sense of self identity.

Given such hypothesis, we consider that it is important, not to confuse this transformation phenomenon with the notion of the Digital Double from Dixon [13]. This performative experiential phenomenon is not an exercise of digital double as technological mirroring, an alter-ego, a spiritual emanation or a manipulable mannequin; it doesn't concern any of Dixon's categories. Rather than a representation of an identity, here, the exercise of digital expanded performance explores a recreation and re-adaptation of the sense of self.

\section{CONCLUSION}

As an artistic manifestation, dance might be considered a practical research of Merleau-Ponty's principles [14], which sustain that perception is always incorporated, and that the body exists as a constant interrelation to the surrounding world. The work of dance, by intensively engaging with proprioception in relation with interoception and exteroception, inherently expands the limits of perception. therefore, following Damásio's theory of consciousness, it also expands the limits of selfconsciousness. The collaboration of dance with digital media arts affords further possibilities in this ground of research. Digital media can convey new concrete frameworks of experiential reality, which are able to expand our sensory and perceptive spectrum, thus providing a innovative perceptual and effector world. In this sense, such interdisciplinary practice has the potential to challenge our Umwelt (concept coined by von Uexkull) [15]. Embodying Sound, provides a new sensorial double modality where sound comes out of movement. Imagine how our framework of experiential reality would be if each of us would generate sounds deriving from our movement? And, if these sounds would be linked with body anatomy, or muscular tension, or space directions, or if they would be depending on our proximity to different substances, how would our consciousness of the self and others transform? How would this

\footnotetext{
${ }^{3}$ In a summarized manner, Damásio's theory explains that the phenomenon of selfconsciousness develops as an incorporated process based on perceptive recursive neurological maps of sensorial information. At an underlying level, there is the proto-self, which mainly concerns to interoceptive maps representing the functional organism. At a core level, there is the nuclear-self, which is generated by the constant pulses that occur by variation of the proto-self, when the exteroceptive and proprioceptive senses interact and map the environment. Finally, Damásio designates the auto-biographic-self, which relates to previous and future maps of experience.
} 
new sensitive and interactive interface modify our relation with the world?

\section{REFERENCES}

[1] M. Minsky. 1998. The society of Mind. New York, Simon \& Schuster,

[2] A. Damásio. 2017. A Estranha Ordem das Coisas - A vida, os sentimentos e as culturas humanas. Lisboa, Temas e Debates.

[3] D. Conquergood. 2002. Interventions and Radical Research. TDR/The Drama Review, 46/1: 145-156.

[4] Y. Harris. 2009. Taking Soundings a Composer' Investigations into Technologies of Navigation. Online Conference Proceedings "MutaMorphosis: Challenging Arts and Sciences", International Conference, Prague 2007. (https://mutamorphosis.wordpress.com/2009/03/03/taking-soundings-acomposeros-investigations-into-technologies-of-navigation/\#more-779)

[5] U.G. Myn, M.V.N. Biomech, M.V.N Link, and M.V.N. Awinda. 2015. Xsens MVN User Manual.

[6] A. Leardini, A. Chiari, U. Della Croce, and A. Cappozzo, 2005. Human movement analysis using stereophotogrammetry Part 3. Soft tissue artefact assessment and compensation. Gait and Posture, 21(2), 212-225. https://doi.org/10.1016/j.gaitpost.2004.05.002.

[7] D. Roetenberg, H. Luinge, and P. Slycke. 2009. Xsens MVN: full 6DOF human motion tracking using miniature inertial sensors. Xsens Technologies, 8, 1-7.

[8] H. Brückner, C. Bartels, and H. Blume. 2011. Pc- based real time sonification of human motion captured by inertial sensors. The 17 th International Conference on Auditory Display.

[9] D. Stern. 2010. Forms of Vitality: Exploring Dynamic Experience in Psychology, the Arts, Psychotherapy, and Development. New York: Oxford University Press.

[10] G. Deleuze and F. Guattari. 2007. Mil Planaltos: Capitalismo e Esquizofrenia 2 Lisbon: Assírio e Alvim.

[11] M. Merleau-Ponty. 2006. O olho e o espirito. Lisboa: Vega, (tradução: Luís Manuel Bernardo).

[12] A. Damásio. 2010. O Livro da Consciência: A Construção do Cérebro Consciente. Lisboa: Circulo de Leitores, (tradução: Luís Oliveira Santos)

[13] S. Dixon. 2007. Digital Performance - A History in New Media in Theater, Dance, Performance Art, and Installtion. Cambridge, Massachusetts, London: MIT Press.

[14] M. Merleau-Ponty. (2005). Phenomenology of Perception. London and New York: Routledge Classics.

[15] J. Uexkull. 1992. A stroll through the worlds of animals and men: A picture book of invisible worlds. Semiotica: Journal of the International Association for Semiotic Studies 89 (4), 319-391. 